\title{
EVALUASI NORMA KEDAULATAN RAKYAT DALAM KONSTITUSI DAN PELAKSANAANNYA DALAM KERANGKA NEGARA HUKUM DEMOKRATIS
}

\author{
1Endang Puji Lesari \\ 2Muh. Risnain \\ ${ }^{1}$ Universitas Muhammadiyah Tangerang \\ Magister Hukum \\ Jalan Perintis Kemerdekaan I Babakan No.33, RT.007/RW.003, Cikokol, Kec. Tangerang, Kota Tangerang, Banten \\ 15118 \\ 2Universitas Mataram \\ Jl. Majapahit No.62, Gomong, Kec. Selaparang, Kota Mataram, Nusa Tenggara Bara.t 83115
}

*kemenhub.epl@gmail.com

\begin{abstract}
The issue of determining the winners of the presidential election, the tenure of president and vice president, the principle of electing the regional head and the legal regime of the regional head are issues that are still not completely regulated in the constitution and need improvement. Several articles in the constitution relating to people's sovereignty should the MPR make changes to article 6 paragraph (3), article 7, article 18 paragraph (4) and article 23 paragraph (2) by looking at the practice of state administration and the dynamic development of democratic life. MPR as an institution that has the authority to change the constitution can carry out the process of changing the constitution according to the mechanism of article 37 of the 1945 Constitution. such as the absence of the presidential treshold regime and separate elections between legislative elections, presidential elections, local elections. Therefore, the Parliament and the President are called upon to amend Law No. 7 of 2017 concerning elections in line with constitutional values
\end{abstract}

KEYWORDS Sovereignty, People and Amendments

\section{INTRODUCTION}

Dua puluh tahun yang lalu telah terjadi sebuah peristiwa ketatanegaraan penting dalam sejarah perjalanan Indonesia sebagai sebuah bangsa, yaitu amandemen konstitusi, Undang Undang Dasar Negara Republik Indonesia (UUD NRI) 1945. Perubahan dilakukan secara addendum, tahap pertama yang dilakukan pada tahun 1999, kemudian tahun 2000, tahun 2001, dan terakhir tahun 2002 adalah perjalanan sejarah ketatanegaraan yang cukup mewarnai perjalanan kehidupan berbangsa dan Negara sekarang dan akan datang. Perjalanan dua puluh tahun perubahan konstitusi diwarnai cukup banyak dinamika kehidupan kehidupan berbangsa dan bernegara yang cukup menguji komitmen kebangsan dan kenegarawan semua komponen bangsa.(Fatwa, 2009; Neta, 2014; Reschentia et al., 2016)

Salah satu persoalan mendasar yang mewarnai perjalanan konstitusi adalah bagaimana melaksanakan kedaulatan rakyat yang sesuai dengan Idiologi Pancasila, 
kepribadian bangsa Indonesia di tengah tuntutan demokratisasi. Itulah sebabnya konstitusi menempatkan pasal tentang kedaulatan rakyat menjadi salah satu prinsip pokok dalam penyelenggaraan negara yang menjadi corner stone bagi keberadaan lembaga Negara lainnya. Pasal kedaulatan rakyat kemudian oleh pembentuk konstitusi ditempatkanpada pasal 1ayat (2) sama kedudukannya dengan bentuk Negara (pasal 1 ayat (1) dan negara hukum sebagai prinsip dasar penyelenggaraan negara.(Dewi, 2017; Irawan, 2016; Sugianto \& Budiarsih, 2018)

Ketiga prinsip pokok yang ada dalam pasal 1 di atas kemudian menjadi umbrella article dan menjadi asas penyelenggaraan negara serta menjadi rujukan bagi keberadaan pasalpasal berikutnya dalam konstitusi. (Akhmaddhian, 2018; Gandaria, 2015) Pasal 1 ayat (1) mengukuhkan bentuk Negara sebagai kesatuan dan menegasikan bentuk Negara federal dan bentuk pemerintahan republik yang menegasikan bentuk Negara monarki. (Asshiddiqie, 2007)Turunannya dapat ditemukan pada Pasal 18 konstitusi. Pasal 1 ayat (2) konstitusi mengatur tentang faham kedaulatan rakyat sebagai pemegang kedaulatan paling tinggi dalam penyelenggaraan negara. (Dewi, 2017; Sinaga, 2013; Sugianto \& Budiarsih, 2018) Turunan pasal ini dapat ditemukan kembali dalam pasal-pasal tentang pemilihan umum (pemilu) yaitu pemilu legislatif, pemilu presiden dan pemilihan kepala daerah. Pasal 1 ayat (3) konstitusi menempatkan prinsip negara hukum (rule of law) sebagai prinsip yang menopang negara kesatuan dan kedaulatan rakyat. Prinsip Negara hukum kemudian diturunkan melalui lembaga peradilan yang merdeka dan independen dalam Pasal 24 dan pengakuan dan perlindungan HAM mulai dari Pasal 26-Pasal 30 konstitusi.(Ananda, 2019; Eddyono, 2016; Muhammad Alim, 2010)

Keberadaan Pasal 1 ayat (2) yang menempatkan "kedaulatan berada di tangan rakyat dan dilaksanakan menurut Undang-Undang Dasar" sebagai pengganti keberadaan kedaulatan rakyat yang sebelum perubahan konstitusi dipegang sepenuhnya Majelis Permusyawaratan Rakyat (MPR) berikut kewenangannya mengalami perubahan fundamental dimana MPR tidak lagi sebagai tertinggi Negara, tidak memiliki kewenangan memilih presiden dan wakil presiden tidak memiliki kewenangan untuk menetapkan Garis Besar Haluan Negara (GBHN). (Dewi, 2017; Marwijah \& Nuswardani, 2014; Rohmat, 2016; Saraswati, 2017; Widayati et al., 2014)Kedaulatan rakyat dijalankan menurut undangundang dasar diterjemahkan melalui pemilihan presiden dan wakil presiden secara langsung oleh rakyat (Pasal 6 ayat 1), pemilihan kepala daerah dipilih secara demokratis (Pasal 18 ayat (4), dan pemilihan anggota DPR RI (Pasal 19 ayat 1), anggota DPRD (Pasal 18 ayat 3), dan anggota DPD (Pasal 19 ayat (1).(Fahmi, 2016; Widjiastuti, 2016)

Namun 20 (dua puluh) tahun setelah amandemen konstitusi banyak dinamika pelaksanaan kedaulatan rakyat yang perlu direviu, dikaji, dan perbaharui baik pada tataran norma konstitusi maupun pelaksanaan kedaulatan rakyat melalui peraturan perundangundangan.(Fatwa, 2009; Mahfud, 2007; Siahaan, 2009) Pada tataran norma konstitusi hingga kini masih diperdebatkan keberadaan Pasal 1 ayat 2 UUD NRI 1945 yang mengubah pelaksanaan kedaulatan rakyat yang sebelumnya dimiliki oleh MPR kemudian ditentukan dilaksanakan langsung oleh rakyat melalui pemilihan umum. (Arrsa, 2016; Nugraha, 2019; Tutik, 2013) Hilangnya kedudukan MPR sebagai pemegang tunggal kedaulatan rakyat menyebabkan hilangnya salah satu kewenangan MPR untuk menetapkan GBHN yang diasumsikan berdampak pada disorientasi pembangunan nasional yang melenceng dari konstitusi, kenyataan inilah kemudian menyebabkan beberapa pihak menginginkan agar GBHN "dihidupkan" kembali sebagai acuan pembangunan nasional. Namun wacana ini akan menuai hambatan ketika kewenangan MPR untuk memilih presiden dan wakil presiden tidak ada lagi, presiden tidak lagi mandataris MPR yang wajib melaksanakan GBHN.(Nugraha, 2019) 
Persoalan lain yang dihadapi pelaksanaan kedaulatan rakyat adalah bagaimana menuangkan prinsip kedaulatan rakyat dalam peraturan perundang-undangan di bawah UUD NRI 1945 agar sejalan dengan semangat Pasal 1 ayat (2) konstitusi yang mengamanatkan pelaksanaan kedaulatan rakyat dilaksnakan berdasarkan konstitusi. Konstitusi kemudian mengatur pelaksanaan kedaulatan rakyat dengan menggunakan istrumen pemilihan umum secara langsung terhadap presiden dan wakil presiden, anggota DPR RI, anggota DPD RI, anggota DPRD, dan kepala daerah. (Nugroho, 2016; Thalib, 2006)Namun disinilah letak persoalan mendasar bagaimana pelaksanaan kedaulatan rakyat berhadapan dengan persoalan yuridis, sosiologis, dan filosofis dalam penyelenggaraan pemilihan umum di Indonesia setelah amandemen konstitusi.(Prasetyoningsih, 2014; Sabriantina, 2008; Sudrajat, 2016)

Persoalan yuridis kebijakan hukum pelaksanaan kedaulatan rakyat melalui pemilu menghadapi persoalan ketika banyak peraturan perundang-undangan yang menimbulkan polemik dalam politik nasional dan berujung dijudicial review oleh masyarakat ke Mahkamah Konstitusi dan Mahkamah Agung karena dianggap bertentangan dengan konstitusi, seperti keberadaan rezim electoral threshold, parlementary threshold, presidential threshold, sistem pemilu proporsional terbuka dalam berbagai peraturan perundang-undangan sebelum diundangkannya Undang-Undang Nomor 7 Tahun 2017 tentang Pemilu, larangan menjadi caleg mantan narapidana korupsi dalam peraturan KPU, rezim pemilu serentak, calon presiden independen, calon kepala daerah independen, pemilihan kepala daerah serentak, penyederhanaan parpol, dll. (Heryanto, 2020; Saleh \& Hunafa, 2018; Sardini et al., 2019)

Pelaksanaan kedaulatan rakyat sedikit banyak berdampak pada pelembagaan kedaulatan rakyat melalui lembaga Negara berikut hubungan antar lembaga Negara. Hingga kini masih berkembang pemikiran untuk memperkuat kewenangan DPD sebagai lembaga perwakilan, hubungan antara lembaga DPD RI dan DPR RI dalam melaksanakan fungsi legislasi, fungsi anggaran, dan fungsi pengawasan. Juga bagaimana hubungan DPD dengan Presiden dalam pelaksanaan fungsi legislasi, fungsi anggaran, dan fungsi pengawasan. Polemik itu kemudian orang mempertanyakan keberadaan koherensi Undang-Undang Nomor 17 Tahun 2014 tentang MPR, DPR, DPD, dan DPRD berikut perubahannya yang tidak jarang berujung pada judicial review di Mahkamah Konstitusi. (Gitawati, 2015)

Pada aspek sosiologis pun tidak kalah bermasalah dengan persoalan yuridis bahkan saling berkaitan di antara keduanya. Sebagai imbas dilaksanakannya pemilu presiden dan wakil presiden yang dilakukan secara serentak pada tanggal 17 April yang lalu menimbulkan korban jiwa sekitar 600 orang petugas KPPS meninggal dunia karena kelelahan mengurus pemilu yang begitu ribet dari pemilu-pemilu sebelumnya sehingga keberadaan pemilu serentak dipertanyakan dan ada gagasan untuk dievaluasi pada pemilu yang akan datang. (Benuf, 2019) Keberadaan rezim presidential threshold dalam UndangUndang Nomor 7 Tahun 2017 dengan mengacu pada hasil pemilu legislatif tahun 2014 berimbas pada keberlanjutan kondisi masyarakat yang terbelah (divided society) yang terjadi sejak 2014 hingga kini karena partai politik kecil dan baru tidak memiliki kesempatan yang sama untuk mengajukan calon presiden dan calon wakil presiden alternatif karena persyaratan 20 persen kursi di parlemen dan perolehan 20 persen suara nasional pada pemilu 2014 tidak terpenuhi. Kondisi masyarakat yang terbelah karena pilihan politik ketika pemilu presiden, belum lagi melihat kenyataan bagaimana terjadi moral hazard seperti money politics dalam pemilu legislatif yang masih terjadi yang juga sebagai imbas dari persaingan antar caleg baik pada internal parpol maupun eksternal partai politik yang begitu bebas sehingga caleg menggunakan segala macam cara untuk meraih kemenangan.(Bandarsyah, 2019; Zuhro, 2019) 
Pada landasan filosofis pelaksanaan kedaulatan rakyat mengalami kondisi kering nuansa filosofis dan jauh dari demokrasi yang dilandasi nilai-nilai Pancasila. Kedaulatan rakyat melalui pemilu yang dilaksanakan dengan prinsip langsung, umum, bebas, rahasia, jujur, dan adil kehilangan makna filofosifnya ketika pemilu diwarnai praktek curang, moral hazard, dan money politic yang melingkupinya. Maka persoalan mendasarnya adalah mengembalikan pemilu yang mencerminkan nilai-nilai pancasila sebagai philosophia grondslag kedaulatan rakyat.

Beranjak uraian di atas menjadi penting untuk mengkaji dan mengevaluasi Pelaksanaan Undang-Undang Dasar Negara Republik Indonesia Tahun 1945 yang telah dilakasanakan selama 20 tahun khususnya berkaitan dengan pelaksanaan kedaulatan rakyat. Tulisan ini akan menelaah pasal-pasal di dalam Undang-Undang Dasar Negara Republik Indonesia Tahun 1945 yang berkaitan dengan kedaulatan rakyat, pasal-pasal yang perlu dilakukan perubahan/penyempurnaan berikut alasannya, mengkaji landasan filosofis, yuridis, dan sosiologis yang mendasari perlunya perubahan penyempurnaan konstitusi dan rekomendasi perbaikan materi aturan dalam konstitusi dan implementasi yang perlu disempurnakan.

\section{METHODOLOGY}

Penelitian hukum normatif (normative law research) menggunakan studi kasus normatif berupa produk perilaku hukum, misalnya mengkaji undang-undang. Pokok kajiannya adalah hukum yang dikonsepkan sebagai norma atau kaidah yang belaku dalam masyarakat dan menjadi acuan perilaku setiap orang. Sehingga penelitian hukum normatif berfokus pada inventarisasi hukum positif, asas-asas dan doktrin hukum, penemuan hukum dalam perkara in concreto, sistematik hukum, taraf sinkronisasi, perbandingan hukum dan sejarah hukum penulis memutuskan menggunakan metode penelitian hukum normatif untuk meneliti dan menulis artikel ini sebagai metode penelitian hukum.

\section{RESULTS AND DISCUSSION}

\section{Perspektif Teoritis Perubahan Konstitusi}

Menurut K.C Wheare konstitusi merupakan keseluruhan sistem ketatanegaraan suatu negara, kumpulan peraturan-peraturan yang mendasar dan mengatur atau mengarahkan pemerintahan. Peraturan-peraturan tersebut ada yang dimaknai hukum dan terdapat juga norma yang bersifat non-hukum. (Munir, 2014) Konstitusi adalah resultan dari berbagai kekuatan politik, ekonomi, dan sosial yang berjalan pada waktu pembentukkannya. Dalam buku yang sama K.C. Wherae mengatakan terdapat beberapa metode perubahan konstitusi, yaitu: pertama, perubahan formal (amandemen formal), kedua, perubahan melalui penafsiran yudisial, dan ketiga, kebiasaan dan tradisi (konvensi ketatanegaraan).(Wheare, 1975)

Perubahan konstitusi sebuah negara bukanlah sebuah hal yang tabu dilakukan. Peristiwa ini hampir dilakukan oleh semua negara, karena sesungguhnya konstitusi bukanlah sebuah kitab suci yang selalu harus "disakralkan" dan tidak boleh disentuh untuk diubah. Indonesia sesungguhnya punya pengalaman yang panjang bagaimana konstitusi diubah dan diganti kemudian pernah juga disakralkan sebagai kitab suci keramat.(Isra, 2009) 
Secara periodik perkembangan konstitusi Indonesia dibagi dalam beberapa periode: konstitusi pertama, periode 18 agustus 1945-27 desember 1949. Disahkan pada 18 agustus 1945 oleh panitia persiapan kemerdekaan Indonesia (PPKI), ketuanya, Ir. Soekarno, wakilnya Dr. M. Hatta. Naskah UUD disiapkan BPUPKI untuk persiapan kemerdekaan Indonesia. UUD yg disahkan PPKI dianggap sah karena merupakan hasil dari revolusi bangsa Indonesia utk merdeka dari penjajah.(Shiddiqie, 2016) UUD bersifat sementara karena UUD yang tetap akan disahkan MPR. Konstitusi kedua: Merupakan UUD RIS 27 Desember 1949 sampai dengan 17 Agustus 1950. Konstitusi dihasilkan dari keinginan Belanda untuk berkuasa kembali di Indonesia melalui agresi militer I (1947) dan II (1948). Diadakan konferensi meja bundar di bawah PBB utk membahasa masalah Indonesia menghasilkan tiga persetujuan pokok: (1). Mendirikan Republik Indonesia Serikat, (2). Penyerahan kedaulatan kepada RIS, (3). Didirikan negara uni antara RI dan kerajaan Belanda. Dibuat naskah UUD antara wakil RI (KNP) dan delegasi BFO. Konstitusi ini disetujui 14 Desember 1949.

Sejak 1950 tersusunlah naskah UUD RIS. Dengan berdirinya RIS maka RI tetap ada dan menjadi salah satu negara bagian dari RIS sama seperti Negara Indonesia Timur, negara pasundan, negara sumatera timur, negara jawa timur, dsb. UUD 1945 hanya berlaku dalam wilayah RI saja, di luar itu berlaku konstitusi RIS. Konstitusi RIS hanya bersifat sementara. (Asshiddiqie, 2010)

Konstitusi ketiga: UUDS 1950 dibentuk untuk menyatukan kembali bentuk negara kesatuan Republik Indonesia karena RIS tidak bertahan lama. Naskah UUDS disahkan oleh BP KNP, DPR dan senat RIS pada 14 Agustus 1950 dan mulai berlaku 27 Agustus 1950. UUD 1950 merupakan perubahan atas UUD RIS melalui Pasal 190, Pasal 127 (a) dan Pasal 191 mengatur tentang prosedur perubahan UUD RIS.

Konstitusi keempat: kembali ke UUD 1945 (5 Juli 1959-19 Oktober 1999). Situasi politik pasca pemilu 1955 untuk memilih anggota konstituante tidak kondusif karena konstituante tidak dapat bersidang sebagamana mestinya. Konstituante tidak berhasil merumuskan UUD yang tetap untuk menggantikan UUDS 1950. Presiden Soekarno mengambil kebijakan mengeluarkan Dekrit Presiden melalui Kepres pada tanggal 5 Juli 1959. Dekrit presiden tersebut dapat diterima dan konstitusional sebagai keadaan yang bersifat staatsnoodrecht (hukum tata negara darurat).

Sejak Dekrit Presiden 5 Juli 1959 naskah UUD 1945 berlaku kembali konstitusi RI dan sebagai hukum tertinggi yang berlaku di NKRI. UUD 1945 masih tetap bersifat sementara dan kepada MPR diberi tugas kewenangan untuk menetapkan UUD 1945. Namun MPR sejak 1977-1997 tidak pernah melakukan tugasnya (sakralisasi UUD 1945.UUD 1945 disamping memiliki naskah pokok (batang tubuh) juga memiliki penjelasan. Menjadi perdebatan apakah penjelasan merupakan bagian dari UUD 1945 atau tidak dan menjadi interpretasi autentik dari UUD 1945. Banyak materi muatan penjelasan UUD yang bertentangan dengan batang tubuh, misalnya. Istilah presiden sebagai kepala negara dan kepala pemerintahan dalm sistem presidensil, tetapi dalam praktek menjadi sistem pemerintahn parlementer, termasuk juga sidang istimewa. (Indrati \& Farida, 2007)

Konstitusi kelima, konstitusi Peralihan (19 Oktober 1999-10 Agustus 2002). Terjadi karena gerakan reformasi nasional yang dipelopori mahasiswa yang menghendaki 
perbaikan dalam penyelenggaraan negara dari orba ke orde reformasi. Periode ini merupakan peralihan konstitusi dari UUD 1945 hasil Dekrit Presiden 1959 menjadi UUD 1945 pasca perubahan yang menuangkan aspirasi reformasi ketetanegaraan (transitional constitution). Perubahan dilakukan empat kali, 1999, 2000, 2001, dan 2002. Dilakukan oleh MPR yang mengalami evolusi kedudukan dari superpower menjadi lembaga negara powerless.

Konstitusi keenam, Konstitusi pasca perubahan UUD 1945 (10 Agustus-sekarang). Reformasi konstitusi telah selesai dilakukan dengan disahkannya perubahan keempat pada 10 Agustus 2002. Perubahan dilakukan oleh Badan Pekerja MPR (BP MPR) dan membentuk panitia ad hoc (Pah I, II, dan III). Menghasilkan 174 substansi baru atau $300 \%$ dari isi UUD sebelumnya.

Pengalaman berkonstitusi kita di atas menunjukkan bahwa konstitusi mengalami dinamika sesuai dengan situasi sosial dan politik. Pertanyaanya apakah gagasan perubahan UUD NRI 1945 yang telah disahkan pada tahun 2002 memiliki landasan sosial, politik, hukum yang mendekati kondisi ketika terjadi perubahan konstitusi di atas. Penulis dapat memastikan bahwa kondisi kehidupan ketatanegaraan saat ini masih aman dan kita mulai menata sistem kehidupan ketatanegaraan kearah yang lebih stabil. Masa transisi konstitusi telah kita lewati selama kurang lebih 14 tahun, dinamika ketatanegaraan masih berada pada situasi yang tidak segenting situasi pada perubahan-perubahan konstitusi yang telah kita lewati. (Mahfud, 2006)

Namun demikian bahwa gagasan perubahan konstitusi bukanlah hal yang tabu dibicarakan di forum akademik maupun forum politik. Bukan zamannya lagi kita menganggap bahwa UUD NRI 1945 adalah kitab suci yang disakralkan. Zaman terus berubah, pergaulan internasional juga terus berubah, konstitusi harus mengikuti perkembangan sosial dan politik yang selalu dinamis. Perubahan konstitusi adalah hal yang jamak saja dilakukan, tinggal menunggu momen dan situasi yang tepat untuk melakukan perubahan. (Arinanto, 2006)

\section{Rezim Kedaulatan Rakyat dalam Konstitusi}

\section{a. Rezim Kedaulatan Rakyat dalam Konstitusi: bentuk dan kelembagaan}

Pasal 1 ayat (2) UUD NRI 1945 pasca perubahan konstitusi telah mengalami perubahan drastis dari MPR sebagai pemegang tunggal menjadi terpencar pada lembaga-lembaga Negara. Begitu juga cara melaksanakan kedaulatan rakyat yang sebelum dilakukan sepenuhnya oleh MPR untuk memilih presiden berubah menjadi dilakukan langsung oleh rakyat sendiri. Kedaulatan rakyat yang dilaksanakan melalu pemilihan umum oleh konstitusi didesain dilaksanakan melalui pemilihan langsung oleh rakyat.

Kostitusi telah mendesain beberapa bentuk pemilihan umum secara langsung yaitu Presiden dan Wakil Presiden, pemilihan anggota DPR, anggota DPR RI, anggota DPD RI, anggota DPRD dan pemilihan kepala daerah. Berikut penulis uraikan desain konstitusional pemilihan umum juga pengaturan dalam undang-undang yang lebih teknis.

1) Pemilihan Presiden dan Wakil Presiden

Desain konstitusi pasca perubahan UUD NRI 1945 mendesain pelaksanaan

kedaulatan rakyat dilakukan melalui pemilihan umum presiden dan wakil 
presiden secara langsung oleh rakyat. Pasal 6A mengatur tentang cara pemilihan presiden dan wakil presiden, mekanisme pencalonan, dan mekanisme penentuan pemenangan dan Pasal 7 mengatur lama masa jabatan presiden dan wakil presiden dan juga pemilihan kembali presiden pada masa jabatan berikutnya. Pasal 6A mengatur "Presiden dan Wakil Presiden dipilih dalam satu pasangan secara langsung oleh rakyat". Pasal 6 A ayat (2) mengatur mekanisme pencalonan "Pasangan calon Presiden dan Wakil Presiden diusulkan oleh partai politik atau gabungan partai politik peserta pemilihan umum sebelum pelaksanaan pemilihan umum".

Pasal A ayat (3) mengatur mekanisme penentuan calon pemenang pemilu "Pasangan calon Presiden dan Wakil Presiden yang mendapatkan suara lebih dari lima puluh persen dari jumlah suara dalam pemilihan umum dengan sedikitnya dua puluh persen suara di setiap provinsi yang tersebar di lebih dari setengah jumlah provinsi di Indonesia, dilantik menjadi Presiden dan Wakil Presiden". Pada Pasal 6 ayat (4) mengatur delegasi pegaturan pemilihan presiden dan wakil presiden dalam undang-undang tersendiri "Tata cara pelaksanaan pemilihan Presiden dan Wakil Presiden lebih lanjut diatur dalam undang-undang".

Pasal 7 mengatur lama dan pemilihan kembali "Presiden dan teri Wakil Presiden memegang jabatan selama lima tahun, dan sesudahnya dapat dipilih kembali dalam jabatan yang sama, hanya untuk satu kali masa jabatan".

Keberadaan pengaturan tentang pemilihan presiden dan wakil presiden secara langsung dalam konstitusi tidak saja berdampak pada pemilihan presiden yang dilakukan secara langsung oleh rakyat, tetapi juga berdampak pada kelembagaan Negara untuk mengejawantahkan kedaulatan rakyat dalam sistem ketatanegaraan. Maka pasal tentang pemilihan presiden dan wakil presiden menjadi pasal jantung dalam penataan masa depan ketatanegaraan. Namun pemilihan presiden dan wakil presiden secara langsung memiliki persoalan yang belum terselesaikan pada tataran pengaturan konstitusi maupun pelaksanaan dalam undang-undang yang lebih teknis. Misalnya persoalan apakah pilpres menggunakan persyaratan dukungan partai politik dengan menggunakan rezim presidential trehsold atau tidak? apakah pemilihan presiden dan wakil presiden dilakukan secara serentak atau tidak dengan pemilihan legislatif? bagaimana menentukkan calon pemenang calon presiden dan wakil presiden yang hanya diikuti oleh dua pasangan calon seperti pada pilpres 2014 dan 2019?

Perubahan mekanisme pemilihan presiden dan wakil presiden ini berdampak pada mekanisme pemilihan presiden dan kelembagaan perwakilan rakyat. Pemilihan presiden dan wakil presiden secara langsung sejak pemilu 2004, 2009, 2014, dan 2019 mengalami dinamika yang luar biasa baik prosedur maupun mekanismenya. Poin penting dalam pemilihan presiden dan wakil presiden adalah menganisme pencalonan dan cara pelaksanaan apakah mencerminkan kedaulatan rakyat dan dilaksanakan sesuai denga prinsip pemilihan umum yang LUBER dan Jurdil.

Undang-Undang Nomor 23 Tahun 2003 tentang Pemilihan Presiden dan Wakil Presiden adalah undang-undang pertama yang mengatur pemilihan 
presiden dan wakil presiden secara langsung. Undang-Undang Nomor 23 Tahun 2003 tentang Pemilihan Presiden dan Wakil Presiden belum mengatur ketentuan tentang presidential trehsold sebagai persyaratan pencalonan, pilpres dilaksanakan dengan cara terpisah dengan pileg, pasangan capres, dan cawapres diikuti oleh lebih dari dua pasangan sehingga keberadaan Pasal 6A ayat (3) tidak terlalu bermasalah karena pemilihan presiden akan dilaksanakan dengan dua tahap. Dapat dikatakan bahwa pada pemilihan presiden dan wakil presiden periode pertama tidak mengalami permasalahan hukum yang begitu rumit.

Pada pilpres 2009 dan pilpres 2014 peraturan tentang pemilu presiden dan wakil presiden mengalami perubahan yang dinamis sesuai perkembangan kehidupan demokrasi. Pada pilpres 2009 dilaksanakan secara terpisah dengan pileg. Hasil perolehan suara pileg pada bulan april dijadikan sebagai dasar pencalonan pilpres pada bulan juli. Pada pilpres tahun 2008 mulai diperkenalkan rezim presidential trehsold sebagai persyaratan pencalonan presiden. Pasal 9 mengatur bahwa pasangan calon pilpres diusulkan oleh partai politik atau gabungan partai politik yang memenuhi persyaratan perolehan suara paling sedikit $20 \%$ suara DPR atau $25 \%$ suara sah nasional dalam pemilu anggota DPR sebelum pelaksanaan pilpres. Keberadaan rezim presidential threshold dipersoalkan di MK melalui judicial review, walaupun MK memutuskan bahwa presidential threshold tidak bertentangan dengan konstitusi. Pada pilpres 2014 dasar hukum penyelenggaraan pilpres tidak berubah masih menggunakan undang-undang nomor 42 tahun 2008 tentang pemilihan presiden dan wakil presiden.

Pada pemilu 2019 diambil kebijakan melakukan kodifikasi undang-undang tentang pemilihan umum melalui Undang-Undang Nomor 7 Tahun 2017 Tentang Pemilihan Umum. Dalam undang-undang rezim hukum pemilu yang diatur secara terpisah sebelumnya melalui 3 undang-undang, yaitu undang-undang pileg, undang-undang pilpres, dan undang-undang penyelenggara pemilu. Khusus pilpres masih beberapa persoalan yang perlu diperdebatkan adalah penyelenggaraan pilpres dan pileg serentak, keberadaan rezim presidential threshold yang sudah tidak sejalan dengan pemilu serentak, penentuan pemenang pilpres jika tidak ada pemenang sebagaimana ditentukan Pasal 6A ayat (3), kebolehan atau tidak seorang calon presiden dan wakil presiden untuk dipilih kembali setelah menjabat dua periode yang terhalang oleh pejabat presiden yang lain dan persoalan lain yang melingkupinya.

\section{2) Pemilihan anggota legislatif.}

Konstitusi juga mendesain pengisian jabatan wakil rakyat yang akan menjadi anggota legislatif di parlemen dilakukan melalui pemilihan langsung oleh rakyat. Konstitusi mengatur pemilihan tiga lembaga perwakilan dalam pasal-pasal khusus. Pasal 18 ayat (3) mengatur tentang mekanisme pengisian jabatan anggota DPRD yang dipilih melalui pemilihan umum, pemerintah daerah provinsi, daerah kabupaten, dan kota memiliki dewan perwakilan rakyat daerah yang anggotaanggotanya dipilih melalui pemilihan umum. 
Pasal 19 ayat (1) mengatur mekanisme pengisian jabatan anggota DPR RI yang dipilih melalui pemilihan umum. Pasal 22 ayat (1) mengatur juga pengisian jabatan anggota DPD dipilih melalui pemilihan umum. Pasal 22 ayat (2) mengatur jumlah anggota DPD dari setiap provinsi jumlahnya sama dan jumlah seluruh dewan perwakilan daerah itu tidak lebih dari sepertiga jumlah anggota dewan perwakilan rakyat.

3) Pemilihan Kepala Daerah.

Konstitusi mendesain pengisian jabatan Gubernur, Bupati dan Walikota masing-masing sebagai Kepala pemerintahdaerah Provinsi, Kabupaten dan Kota tidak sejelas pemilihan presiden dan wakil presiden dan pemilihan anggota legislatif yang dipilih melalui pemilihan langsung oleh rakyat. Ketentuan Pasal 18 ayat (4) mengatur pengisian jabatan Gubernur, Bupati, dan Walikota dengan mekanisme yang minimalis dan multi-tafsir dengan dipilih secara demokratis. Keberadaan secara demokratis menimbulkan makna ganda apakah dipilih secara demokratis itu bermakna demokrasi langsung melalui pemilihan langsung oleh rakyat atau pemilihan oleh anggota DPRD. Polemik tidak berhenti pada persoalan teknis tetapi berhulu pada persoalan apakah pilkada merupakan rezim pemilu atau bukan rezim. Pengakuan pilkada sebagai pemilu penting agar dapat menentukan bahwa sistem pemilu dapat dilaksanakan pada pilkada termasuk penyelesaian sengketanya.

Pemaknaan demokrasi langsung dan tak langsung pernah dilakukan dengan kelebihan dan kekurangan yang meliputinya. Pemilihan langsung kepala daerah melalui pemilihan langsung pernah dilakukan sejak tahun 2005 dengan segala dinamika dan kekurangannya kemudian dievaluasi untuk dipikirkan pelaksanaanya. Pada tahun 2014 melalui Undang-Undang Nomor 17 Tahun 2014 pemaknaan kata demokratis dilaksanakan melalui lembaga perwakilan dengan memberikan kepada DPRD untuk memilih kepala daerah. Keberadaan undangundang tersebut menuai polemik dan menimbulkan demonstrasi menolak UU tersebut di berbagai daerah di Indonesia. Mantan Presiden Susilo Bambang Yudhoyono kemudian merespon dengan mengeluarkan Perpu No.1 Tahun 2015 tentang Pemilihan Kepala Daerah. Walaupun pada akhirnya pemerintah dan DPR mengundangkan undang-undang pilkada tersendiri namun pada tataran pelaksanaannya pilkada masih menyisakan masalah terkait penyelesaian sengketa pilkada, keberadaan calon tunggal, money politic, potensi konflik sosial.

Disamping persoalan praktikal yang disampaikan di atas maka persoalan esensi dari pilkada secara demokratis adalah sifatnya yang tidak multi-tafsir dan tidak inline dengan rezim pilpres dan pileg yang merupakan rezim pemilu dengan infrastrukur dan suprastruktur politik yang melingkupinya. Oleh karena itu perlu perubahan dan keberanian untuk menentukan rezim pilkada dalam pemilu atau bersifat sui generis dari rezim pemilu.

Dengan demikian keberadaan Pasal 18 ayat (4) harus dimaknai satu nafas dengan keberadaan Pasal 22 yang mengatur prinsip pemilu yang dilaksanakan secara langsung, umum, bebas, rahasia, jujur, dan adil setiap lima 
tahun sekali. Ruang lingkup pemilu meliputi pemilihan umum diselenggarakan untuk memilih anggota dewan perwakilan rakyat, dewan perwakilan daerah, presiden dan wakil presiden dan dewan perwakilan rakyat daerah. Begitu juga dengan peserta pemilu legislatif adalah partai politik, sedangkan peserta pemilihan umum untuk memilih anggota dewan perwakilan daerah adalah perseorangan. Dan dilaksanakan oleh suatu komisi pemilihan umum yang bersifat nasional, tetap dan mandiri.

\section{b. Gagasan Perubahan Konstitusi tentang kedaulatan rakyat: rasio legis pertimbangan yuridis, sosiologis dan filosofis}

Gagasan kedaulatan rakyat yang dituangkan dalam Pasal 1 ayat (2) UUD NRI 1945 tidak selamanya sejalan dengan ketentuan lain dalam konstitusi apalagi pada tataran pelaksanaan. Oleh karena itu perlu dievaluasi dan disempurnakan agar konstitusi yang dibentuk sejalan dengan perkembangan kehidupan demokrasi dan ketatanegaraan yang semakin dinamis. Penulis mengidentifikasi beberapa pasal dalam konstitusi khusunya berkaitan dengan kedaulatan rakyat berikut alasan perubahan (rational legis) dan usulan perubahnnya.

\section{1) Penentuan Pemenang Pemilihan Presiden dan Wakil Presiden}

Konstitusi yang baik adalah konstitusi yang mengikuti perkembangan zaman dan dinamika ketatanegaraan yang begitu cepat berubah. Tidak semua peristiwa politik yang terjadi kemudian telah diatur dan diantisipasi dalam konstitusi oleh karena itu ia berkembang sesuai dengan perkembangan zaman. Salah satu persoalan yang mengemuka sehingga hamper tidak terpecahkan adalah persoalan menentukkan pemenang pilpres.

Pasal 6A ayat (3) mengatur mekanisme penentuan calon pemenang pemilu "Pasangan calon Presiden dan Wakil Presiden yang mendapatkan suara lebih dari lima puluh persen dari jumlah suara dalam pemilihan umum dengan sedikitnya dua puluh persen suara di setiap provinsi yang tersebar di lebih dari setengah jumlah provinsi di Indonesia, dilantik menjadi Presiden dan Wakil Presiden".

Pasal 6 ayat (4) mengatur dalam hal tidak ada pasangan calon presiden dan wakil presiden terpilih dua pasangan calon yang memperoleh suara terbanyak pertama dan kedua dalam pemilihan umum dipilih oleh rakyat secara langsung dan pasangan yang memperoleh suara rakyat terbanyak dilantik sebagai presiden dan wakil presiden".

Desain Pasal 6 ayat (3) dan ayat (4) di atas adalah ketika pemilihan umum diikuti oleh lebih dari dua pasangan, namun tidak mengantisipasi ketika hanya ada 2 (dua) pasangan calon sebagaimana terjadi pada pilpres 2014 dan pilpres 2019 yang hanya diikuti dua pasangan calon. Ini dapat menjadi persoalan konstitusional yang komplek manakala tidak diatur secara detail dalam konstitusi. Oleh karena itu penulis menyarankan penambahan pasal menjadi Pasal 6 ayat (5) "Dalam hal terdapat dua pasangan calon yang mengikuti pemilihan presiden maka 
pemenang pemilihan presiden dan dapat dilantik menjadi presiden dan wakil presiden adalah pasangan yang memperoleh suara terbanyak".

\section{2) Masa Jabatan Presiden dan Wakil Presiden}

Masalah yang muncul dalam pemilihan presiden adalah polemic tentang ketidakjelasan masa jabatan presiden dan wakil presiden, keberadaan norma dalam pasal 7 diperdebatkan bahkan ke MK ketika bunyi pasal 7 yang menyatakan presiden dan wakil presiden memegang jabatan selama lima tahun dan sesudahnya dapat dipilih kembali dalam jabatan yang sama, hanya untuk satu kali masa jabatan. dihadapkan pada praktek ketatanegaraan manakala wakil presiden Jusuf Kalla yang pernah menjabat sebagai wapres dari Presiden SBY jilid pertama (2004-2009) kemudian tidak menjabat wapres ketika SBY jilid 2 dari tahun 20092014, kemudian menjabat wapres ketika Joko Widodo sebagai Presiden (20142019). Realita ketatanegaraan ini kemudian menimbulkan persoalan apakah jabatan Jusuf Kalla dianggap dua periode atau masih 1 periode sehingga ia dapat mencalonkan diri sebagai wapres atau presiden pada pilpres berikutnya?

Menurut penulis masalah ini harus diatur secara jelas dalam konstitusi karena konstitusi hanya mengatur secara sumir dan hanya dengan satu ayat saja. Menurut penulis Pasal 7 harus ditambah dengan satu ayat yang memperjelas ayat (1), sehingga Pasal 7 berbunyi:

a) Presiden dan Wakil Presiden memegang jabatan selama lima tahun, dan sesudahnya dapat dipilih kembali dalam jabatan yang sama, hanya untuk satu kali masa jabatan.

b) Dalam hal Wakil Presiden pernah dijabat oleh salah satu pasangan kemudian diselingi oleh pejabat lain dan ia menjabat dengan jabatan yang sama berikutnya maka jabatan tersebut dianggap jabatan yang sama.

c) Pengisian Jabatan Kepala Daerah

Desain konstitusi tentang pengisian jabatan kepala daerah dengan menggunakan mekanisme demokratis memiliki kelemahan karena tidak mengikuti perkembangan rezim kedaulatan rakyat yang secara umum telah menggunakan mekanisme pemilihan langsung seperti pileg dan pilpres dan multitafsir. Maka menurut penulis pemilihan kepala daerah juga harus mengikuti kecenderungan umum demokrasi Indonesia. Di samping itu praktek pilkada selama ini membuktikan bahwa pilkada memiliki kesamaan dengan pilpres dengan pileg sementara konstitusi belum secara jelas menggunakan rezim pemilihan langsung. Persoalan ini sebenarnya menyulitkan dari segi konstitusionalitas pilkada langsung selama dan juga prakteknya termasuk persoalan penyelenggara, anggaran, dan rezim penyelesaian sengketa pemilu.

Oleh karena itu menurut penulis konstitusi harus berani mengambil perubahan dengan mengikuti kecenderungan dan praktek demokrasi langsung yang selama ini praktekan.

Menurut penulis pasal 18 ayat (4) yang berbunyi Gubernur, Bupati dan Walikota masing-masing sebagai kepala Pemerintah Daerah Provinis, Kabupaten 
dan Kota dipilih secara demokratis dan berubah menjadi Gubernur, Bupati, dan Walikota masing-masing sebagai kepala pemerintah daerah provinsi, kabupaten dan kota dipilih secara langsung oleh rakyat.

\section{3) Rezim pemilihan kepala daerah}

Sejalan dengan mekanisme pemilihan kepala daerah yang diusulkan dipilih secara langsung oleh rakyat sebagaimana diusulkan di atas maka langkah selanjutnya adalah dengan memasukkan rezim pemilihan kepala daerah dalam rezim pemilu. Hal ini penting dilakukan sebagai bentuk pengakuan atas rezim pilkada sebagai bagian dari rezim hukum pemilu. Dengan penyatuan rezim ini tidak ada lagi perdebatan tentang penyelenggara pilkada, anggaran pilkada, dan juga penyelesaian sengketa pilkada.

Ketentuan pasal $22 \mathrm{E}$ ayat (2) yang mengatur bahwa pemilihan umum diselenggarakan untuk memilih anggota dewan perwakilan rakyat, dewan perwakilan daerah, presiden dan wakil presiden dan dewan perwakilan rakyat daerah, presiden dan wakil presiden dan dewan perwakilan rakyat daerah tidak mencantumkan pemilihan kepala daerah menyebabkan kesulitan-kesulitan teknis pilkada. Oleh karena itu mengatasi persoalan tersebut maka pasal 22 E ayat (2) yang mengatur bahwa pemilihan umum diselenggarakan untuk memilih anggota dewan perwakilan rakyat, dewan perwakilan daerah, presiden dan wakil presiden dan dewan perwakilan rakyat daerah, presiden dan wakil presiden dan dewan perwakilan rakyat dan kepala daerah.

Keberadaan ayat ini memberikan kejelasan konstitusional tentang penyelesaian sengketa pilkada yang selama ini secara yuridis masih "digantung" karena ketiadaan lembaga penyelesain sengketa PHPU pasca MK menyatakan diri tidak memiliki yurisdiksi untuk menyelesaikan sengketa pilkada. Dengan memasukkan pilkada dalam rezim hukum pemilu maka mengukuhkn MK sebagai lembaga yang memiliki yurisdiksi permanen menyelesaikan sengketa pilkada.

Untuk lebih jelasnya usulan perubahan pasal dalam konstitusi yang berkaitan dengan kedaulatan ralyat di atas berikut penulis uraikan dalam matriks berikut ini: 


\begin{tabular}{|c|c|c|c|}
\hline NO & RUANG LINGKUP & $\begin{array}{c}\text { KETENTUAN PASAL DALAM UUD } \\
\text { NRI } 1945\end{array}$ & $\begin{array}{c}\text { USUL } \\
\text { PERUBAHAN/PENAMBAHAN }\end{array}$ \\
\hline 1. & $\begin{array}{l}\text { Penentuan } \\
\text { Pemenang } \\
\text { Pemilihan } \\
\text { Presiden dan } \\
\text { Wakil Presiden }\end{array}$ & $\begin{array}{l}\text { Pasal (6 ayat } 3) \\
\text { Pasangan calon Presiden dan Wakil } \\
\text { Presiden yang mendapatkan suara } \\
\text { lebih dari lima puluh persen dari } \\
\text { jumlah suara dalam pemilihan } \\
\text { umum dengan sedikitnya dua puluh } \\
\text { persen suara di setiap provinsi yang } \\
\text { tersebar di lebih dari setengah } \\
\text { jumlah provinsi di Indonesia, } \\
\text { dilantik menjadi Presiden dan Wakil } \\
\text { Presiden } \\
\text { Pasal ( } 6 \text { ayat } 3) \\
\text { dalam hal tidak ada pasangan calon } \\
\text { Presiden dan Wakil Presiden ter } \\
\text { pilih dua pasangan calon yang me } \\
\text { mperoleh suara terbanyak pertam } \\
\text { a dan kedua dalam pemilihan umu } \\
\text { m dipilih oleh rakyat secara lang } \\
\text { sung dan pasangan yang memper } \\
\text { oleh suara rakyat terbanyak dilan } \\
\text { tik sebagai Presiden dan Wakil Pr } \\
\text { esiden }\end{array}$ & $\begin{array}{l}\text { pasal } 6 \text { ayat (5) "Dalam hal } \\
\text { terdapat dua pasangan calon } \\
\text { yang mengikuti pemilihan } \\
\text { presiden maka pemenang } \\
\text { pemilihan presiden dan dapat } \\
\text { dilantik menjadi presiden dan } \\
\text { wakil presiden adalah pasangan } \\
\text { yang memperoleh suara } \\
\text { terbanyak" }\end{array}$ \\
\hline 2. & $\begin{array}{l}\text { Masa Jabatan } \\
\text { Presiden dan Wa } \\
\text { kil Presiden }\end{array}$ & $\begin{array}{l}\text { Pasal } 7 \\
\text { Presiden dan Wakil Presiden me } \\
\text { megang jabatan selama lima tahu } \\
\text { n, dan sesudahnya dapat dipilih k } \\
\text { embali dalam jabatan yang sama, } \\
\text { hanya untuk satu kali masa jabata } \\
\text { n. }\end{array}$ & $\begin{array}{l}\text { Pasal } 7 \text { ayat (2) } \\
\text { Dalam hal Wakil Presiden } \\
\text { pernah dijabat oleh salah satu } \\
\text { pasangan kemudian diselingi } \\
\text { oleh pejabat lain dan ia menjabat } \\
\text { dengan jabatan yang sama } \\
\text { berikutnya maka jabatan } \\
\text { tersebut dianggap jabatan yang } \\
\text { sama }\end{array}$ \\
\hline 3. & $\begin{array}{l}\text { Pengisian Jabatan } \\
\text { Kepala Daerah }\end{array}$ & $\begin{array}{l}\text { Pasal } 18 \text { ayat (4) } \\
\text { Gubernur, Bupati dan Walikota m } \\
\text { asing-masing sebagai Kepala Pem } \\
\text { erintah daerah Provinsi, Kabupate } \\
\text { n dan Kota dipilih secara demokrati } \\
\text { s }\end{array}$ & $\begin{array}{l}\text { Pasal } 18 \text { ayat (4) } \\
\text { Gubernur, Bupati dan Walikot } \\
\text { a masing-masing sebagai Kepa } \\
\text { la Pemerintah Daerah Provinsi, } \\
\text { Kabupaten dan Kota dipilih sec } \\
\text { ara langsung oleh rakyat" }\end{array}$ \\
\hline 4. & $\begin{array}{l}\text { Rezim pemilihan } \\
\text { kepala daerah }\end{array}$ & $\begin{array}{l}\text { Pasal } 23 \text { ayat (2) } \\
\text { Pemilihan umum diselenggarakan u } \\
\text { ntuk memilih anggota Dewan Perw } \\
\text { akilan Rakyat, Dewan Perwakilan } \\
\text { Daerah, Presiden dan Wakil Presid } \\
\text { en dan Dewan Perwakilan Rakyat } \\
\text { Daerah }\end{array}$ & $\begin{array}{l}\text { Pasal } 23 \text { ayat (2) } \\
\text { Pemilihan umum diselenggarak } \\
\text { an untuk memilih anggota Dewa } \\
\text { n Perwakilan Rakyat, Dewan Pe } \\
\text { rwakilan Daerah, Presiden dan } \\
\text { Wakil Presiden dan Dewan Per } \\
\text { wakilan Rakyat Daerah dan } \\
\text { kepala daerah }\end{array}$ \\
\hline
\end{tabular}

\section{CONCLUSION}

1. Kedaulatan rakyat sebagai salah satu pilar Negara hukum demokratis dalam konstitusi sesungguhnya memiliki kelemahan pada tataran norma seperti persoalan ketatanegaraan yang kompleks yang perlu disempurnakan sesuai dengan perkembangan kehidupan ketatanegaraan yang dinamis. Persoalan penentuan pemenang pilpres, masa jabatan presiden dan wakil presiden, prinsip pemilihan kepala daerah dan rezim hukum kepada daerah adalah persoalan yang masih belum tuntas diatur dalam konstitusi dan butuh penyempurnaan. Ketiadaan norma dan 
ketidakjelasan norma norma konstitusi menyebabkan kesulitan konstitusional dalam pelaksanaan kedaulatan rakyat melalui instrument pemilihan umum.

2. Model perubahan norma melalui amandemen konstitusi adalah langkah tepat untuk penyempurnaan norma konstitusi yang masih memiliki kelemahan. Beberapa norma konstitusi seperti penentuan pemenang pilpres, masa jabatan presiden dan wakil presiden, prinsip pemilihan kepala daerah dan rezim hukum kepada daerah dalam rezim pemilihan umum adalah terobosan untuk menyempurnakan pelaksanaan kedaulatan rakyat dalam Negara hukum demokratis.

\section{REFERENCES}

Akhmaddhian, S. (2018). Asas-Asas dalam Penyelenggaraan Pemerintahan yang Baik untuk Mewujudkan Good Governance. LOGIKA: Jurnal Penelitian Universitas Kuningan, 9(01). Ananda, S. (2019). Reformulasi Kewenangan Komisi Yudisial Dalam Perspektif Penegakan Kode Etik Pada Lembaga Peradilan [PhD Thesis].

Arinanto, S. (2006). Politik Pembangunan Hukum Nasional dalam Era Pasca Reformasi. Jurnal Konstitusi, 3.

Arrsa, R. C. (2016). Pemilu Serentak dan Masa Depan Konsolidasi Demokrasi. Jurnal Konstitusi, 11(3), 515-537.

Asshiddiqie, J. (2007). Pokok-Pokok Hukum Tata Negara Indonesia Pasca Reformasi. Bhuana Ilmu Populer.

Asshiddiqie, J. (2010). Perihal undang-undang. Rajawali Pers.

Bandarsyah, D. (2019). Pemilu Indonesia dan Tantangan Era Milenial. Salam Redaksi.

Benuf, K. (2019). Harmonisasi Hukum: Pemilu Serentak dan Ketenagakerjaan, Analisis Yuridis terhadap Kematian KPPS Tahun 2019. Gema Keadilan, 6(2), 196-216.

Dewi, N. W. M. S. (2017). Kewenangan MPR sebagai Pelaksana Kedaulatan Rakyat Pasca Amandemen Ke-4 UUD NRI 1945. SOSHUM: Jurnal Sosial Dan Humaniora [Journal of Social Sciences and Humanities], 7(1), 1-11.

Eddyono, L. W. (2016). Penyelesaian Sengketa Kewenangan Lembaga Negara oleh Mahkamah Konstitusi. Jurnal Konstitusi, 7(3), 001-048.

Fahmi, K. (2016). Prinsip Kedaulatan Rakyat dalam Penentuan Sistem Pemilihan Umum Anggota Legislatif. Jurnal Konstitusi, 7(3), 119-160.

Fatwa, A. M. (2009). Potret konstitusi pasca amandemen UUD 1945. Penerbit Buku Kompas. Gandaria, R. Y. (2015). Implementasi Asas-Asas Umum Pemerintahan Yang Baik (Aaupb) Dalam Mewujudkan Prinsip Good Governance And Clean Government Di Pemerintahan Daerah. Lex Administratum, 3(6). 
Gitawati, D. F. (2015). Implikasi Undang-Undang Nomor 17 Tahun 2014 Tentang MPR, DPR, DPD, dan DPRD Terhadap Kewenangan DPR RI Dalam Hal Penentuan Pimpinan DPR Dan Hak Imunitas DPR. [PhD Thesis]. University of Muhammadiyah Malang.

Heryanto, G. G. (2020). Realitas Komunikasi Politik Indonesia Kontemporer. IRCISOD.

Indrati, M. F., \& Farida, M. (2007). Ilmu Perundang-Undangan: Jenis, Fungsi dan Materi Muatan. Yogyakarta: Kanisius.

Irawan, A. (2016). Implementasi Teori Kedaulatan Rakyat Negara Republik Indonesia Di Lembaga Dewan Perwakilan Rakyat. ETD Unsyiah.

Isra, S. (2009). Kekuasaan dan perilaku korupsi: Catatan hukum. Penerbit Buku Kompas.

Mahfud, M. (2006). Membangun politik hukum, menegakkan konstitusi. LP3ES.

Mahfud, M. (2007). Perdebatan hukum tata negara: Pasca amandemen konstitusi. LP3ES.

Marwijah, S., \& Nuswardani, N. (2014). Garis-Garis Besar Haluan Negara sebagai Penentu Arah dan Strategi Rencana Pembangunan Indonesia. Rechtidee, 9(1), 88-103.

Muhammad Alim, S. H. (2010). Asas-Asas Negara Hukum Modern Dalam Islam; kajian Komprehensif Islam dan Ketatanegaraan. LKIS PELANGI AKSARA.

Munir, S. (2014). The Identical Value Between Constitution and Constitutional Law in the Constitutional System. Jurnal IUS Kajian Hukum Dan Keadilan, 2(2).

Neta, Y. (2014). Eksistensi Komisi Konstitusi Independen Dalam Melakukan Perubahan Undang-Undang Dasar Tahun 1945. JURNAL KONSTITUSI, 1(1).

Nugraha, H. S. (2019). MPR DAN URGENSI GARIS BESAR HALUAN NEGARA DALAM SISTEM KETATANEGARAAN INDONESIA. Veritas et Justitia, 5(1), 191-217.

Nugroho, W. (2016). Politik Hukum Pasca Putusan Mahkamah Konstitusi atas Pelaksanaan Pemilu dan Pemilukada di Indonesia. Jurnal Konstitusi, 13(3), 480-502.

Prasetyoningsih, N. (2014). Dampak Pemilihan Umum serentak bagi pembangunan demokrasi Indonesia. Media Hukum, 21(2), 23.

Reschentia, B., Indra, M., \& Junaidi, J. (2016). Prosedur Perubahan Undang-undang Dasar Negara Republik Indonesia Tahun 1945 Sebelum Dan Sesudah Perubahan [PhD Thesis]. Riau University.

Rohmat, A. M. (2016). Kedudukan dan Kewenangan Majelis Permusyawaratan Rakyat Dalam Era Reformasi. Jurnal Pembaharuan Hukum, 3(2), 181-190.

Sabriantina, T. (2008). Pemilihan Umum Kepala Daerah Sebagai Aktivitas Pemililihan Umum. KONSTITUSI Jurnal, 1(1), 40.

Saleh, M., \& Hunafa, D. F. (2018). Pemilu Berintegritas: Menggagas Pencabutan Hak Politik Bagi Narapidana Tindak Pidana Korupsi yang Dipilih Melalui Pemilihan Umum. Law Research Review Quarterly, 4(03), 1069-1086. 
Saraswati, P. S. (2017). Pemberlakuan Kembali Garis Besar Haluan Negara (GBHN) dalam Undang-Undang Dasar. Prosiding Seminar Nasional Fakultas Hukum Universitas Mahasaraswati Denpasar, 235-243.

Sardini, N. H., Putranti, I. R., Wijayanto, S., Prayitno, T. H., Fitriyah, M. A., \& Alfirdaus, L. K. (2019). Prosiding Konferensi Nasional Rumpun Disiplin Ilmu Politik" Pemilu Dalam Tinjauan Multiaspek".

Shiddiqie, J. A. (2016). Pengantar ilmu hukum tata negara. Rajawali Pers.

Siahaan, M. (2009). Peran Mahkamah Konstitusi dalam Penegakan Hukum Konstitusi. Jurnal Hukum Ius Quia Iustum, 16(3), 357-378.

Sinaga, B. N. (2013). Inkonsistensi Kedaulatan Rakyat dalam Undang-Undang Dasar Negara Republik Indonesia Tahun 1945. Kanun: Jurnal Ilmu Hukum, 15(1), 27-39.

Sudrajat, H. (2016). Kewenangan Mahkamah Konstitusi Mengadili Perselisihan Hasil Pemilukada. Jurnal Konstitusi, 7(4), 159-178.

Sugianto, F., \& Budiarsih, B. (2018). PENGUATAN INSTITUSI KEDAULATAN RAKYAT SEBAGAI IMPLEMENTASI DEMOKRASI PANCASILA. SEMINAR NASIONAL CALL FOR PAPER \& PENGABDIAN MASYARAKAT, 1(01).

Thalib, A. R. (2006). Wewenang Mahkamah Konstitusi \& Implikasinya dalam Sistem Ketatanegaraan RI. Citra Aditya Bakti.

Tutik, T. T. (2013). Analisis Kedudukan dan Status Hukum Ketetapan MPR RI Berdasarkan Undang-Undang Nomor 12 Tahun 2011 tentang Pembentukan Peraturan PerundangUndangan. Jurnal Hukum Ius Quia Iustum, 20(1), 1-20.

Wheare, K. C. (1975). Modern Constitutions. London: Oxford University Press.

Widayati, W., Absori, A., \& Azhari, A. F. (2014). Rekonstruksi Kedudukan Ketetapan Mpr dalam Sistem Ketatanegaraan Indonesia. Media Hukum, 21(2), 15.

Widjiastuti, A. (2016). PRINSIP KEDAULATAN RAKYAT DALAM PENYELENGGARAAN PEMILIHAN UMUM INDONESIA.

Zuhro, R. S. (2019). Demokrasi dan Pemilu Presiden 2019. Jurnal Penelitian Politik, 16(1), 69-81. 